\title{
Wine Spoilage Yeasts: Control Strategy
}

\author{
Carlos Escott, Iris Loira, Antonio Morata, \\ María Antonia Bañuelos and \\ José Antonio Suárez-Lepe \\ Additional information is available at the end of the chapter \\ http://dx.doi.org/10.5772/intechopen.69942
}

\begin{abstract}
Traditionally in winemaking, sulphur dioxide $\left(\mathrm{SO}_{2}\right)$ is chemically the most widely used for microflora control as antimicrobial preservative. Other tested compounds for selective yeast control are sorbic and benzoic acids. Herein, we discuss the effectiveness and the application of traditional and novel treatments and biotechnologies for chemical and biological control of wine spoilage yeasts. The versatility of the killer toxins and the antimicrobial properties of natural compounds such as carvacrol, essential oils and bioactive peptides will be considered. Some of the wine spoilage yeasts that are intended to control belong to the genera Zygosaccharomyces, Saccharomycodes and Dekkera/Brettanomyces, but also the non-Saccharomyces yeasts species dominating the first phase of fermentation (Hanseniaspora uvarum, Hansenula anomala, Metschnikowia pulcherrima, Wickerhamomyces anomalus) and some others, such as Schizosaccharomyces pombe, depending on the kind of wine to be produced.
\end{abstract}

Keywords: spoilage yeasts, essential oils, bioactive peptides, winemaking, wine, emerging biotechnologies, killer toxins, monitoring techniques

\section{Introduction}

Ever since the wild yeast colonies are controlled in grape musts, the fermentation has produced wine with differentiated organoleptic attributes. The control over yeast colonies during the entire winemaking process has given the winemaker the possibility of moulding these characteristics towards producing wine with better quality parameters.

Even though yeasts are responsible for transforming grape must into wine through fermentation, there are yeasts capable of spoiling it (Figure 1). Spoiling yeasts are, in most cases, 

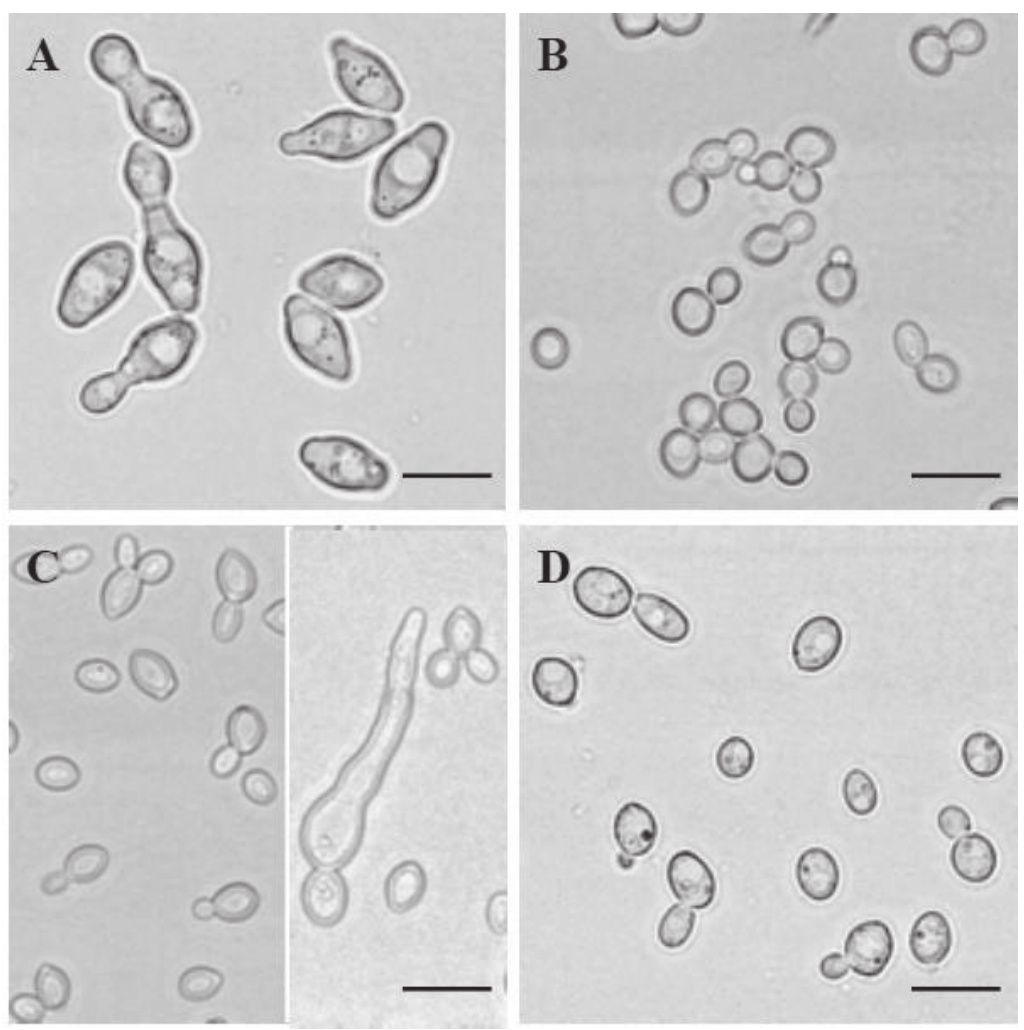

Figure 1. Optical microscopic images of some spoilage yeasts found in wine. (A) S. ludwigii; (B) Z. rouxii; (C) Dekkera spp.; (D) P. anomala. Bar scale: $10 \mu \mathrm{m}$.

resistant to harsh conditions such as high ethanol concentration, relatively low $\mathrm{pH}$ and lethal concentration of sulphites $\left(\mathrm{SO}_{2}\right)$ or dimethyl dicarbonate (DMDC) used as antimicrobial agents.

Some yeast genera can be considered as spoilage microorganisms due to their undesirable implantation in food in which they can cause nutritional and sensory quality degradation and consequently lead to major economic losses. Even their implication in relation to public health is currently under suspicion [1]. Table 1 summarizes some yeast genera known as wine spoilage that also spoils certain food products, particularly specifying the main compounds affecting quality and the effect produced together with potential health hazard.

The uncontrolled use and misuse of antibiotics has caused increasing resistance in a broad group of pathogenic microorganisms, including food-borne pathogens, which, in addition to resisting the effect of antibiotics, are able to survive the processes of food preservation [16].

In this chapter, different technologies and treatments for the control of spoilage yeasts have been revised. These techniques were split into early and emerging technologies in accordance 


\begin{tabular}{|c|c|c|c|c|}
\hline Yeast species & Food product & Spoilage compounds & Effect observed & Health hazard \\
\hline \multirow[t]{4}{*}{$\begin{array}{l}\text { Zygosaccharomyces } \\
\text { rouxii }\end{array}$} & $\begin{array}{l}\text { Products with } 50 \% \\
\text { sugar }[2,3]\end{array}$ & Alcohol, esters [3] & $\begin{array}{l}\text { Gas production: bubbling and } \\
\text { package expansion [3] }\end{array}$ & \\
\hline & Sweet wines [4] & & $\begin{array}{l}\text { Refermentation and } \mathrm{CO}_{2} \\
\text { production [4] }\end{array}$ & \\
\hline & $\begin{array}{l}\text { Mould-ripened soft } \\
\text { cheeses [5] }\end{array}$ & & & \\
\hline & $\begin{array}{l}\text { Fruit juices, sauces, } \\
\text { carbonated soft } \\
\text { drinks, salad } \\
\text { dressings, ketchup } \\
{[3,6]}\end{array}$ & Alcohol, esters [3] & $\begin{array}{l}\text { Gas production: bubbling and } \\
\text { package expansion [3] }\end{array}$ & \\
\hline $\begin{array}{l}\text { Brettanomyces } \\
\text { bruxellensis }\end{array}$ & $\begin{array}{l}\text { Bulk, barrel matured } \\
\text { and bottled wines } \\
{[7,8]}\end{array}$ & $\begin{array}{l}\text { 4-ethylphenol, } \\
\text { 4-ethylguaiacol, } \\
\text { acetic acid [7] } \\
\text { Tetrahydropyridines } \\
\text { [8] }\end{array}$ & $\begin{array}{l}\text { Off aromas, cloudiness } \\
\text { formation in sparkling wine, } \\
\text { mousy aroma [7] } \\
\text { Unpleasant mousy and } \\
\text { medicinal taints [8] }\end{array}$ & \\
\hline \multirow[t]{3}{*}{ Pichia anomala } & $\begin{array}{l}\text { Dairy and baking } \\
\text { products, beer, high } \\
\text { salt environments } \\
\text { and silage [9] }\end{array}$ & & & $\begin{array}{l}\text { No restriction } \\
\text { on handling } \\
\text { and no risk } \\
\text { to healthy } \\
\text { persons [9] }\end{array}$ \\
\hline & $\begin{array}{l}\text { Lactic acid-rich } \\
\text { products [10] }\end{array}$ & & & \\
\hline & $\begin{array}{l}\text { Wine, winemaking } \\
{[7,8]}\end{array}$ & $\begin{array}{l}\text { Ethyl acetate [7] } \\
\text { Acetaldehyde, esters, } \\
\text { acetic acid [8] }\end{array}$ & Oxidation of ethanol [8] & \\
\hline \multirow[t]{2}{*}{$\begin{array}{l}\text { Pichia } \\
\text { guilliermondii }\end{array}$} & Grape juice [7] & 4-ethylphenol [7] & $\begin{array}{l}\text { Off-odours barnyard-like or } \\
\text { horsey [7] }\end{array}$ & \\
\hline & Soft drinks [6] & & & \\
\hline $\begin{array}{l}\text { Pichia } \\
\text { membranaefaciens }\end{array}$ & $\begin{array}{l}\text { Mould-ripened soft } \\
\text { cheeses [5] }\end{array}$ & Acetaldehyde [11] & Chalky film layer [11] & \\
\hline \multirow[t]{3}{*}{$\begin{array}{l}\text { Saccharomycodes } \\
\text { ludwigii }\end{array}$} & $\begin{array}{l}\text { Food products with } \\
\mathrm{SO}_{2} \text { as antiseptic [2] }\end{array}$ & & & \\
\hline & Bottled wines [7] & & $\begin{array}{l}\text { Spoilage by sediment or } \\
\text { cloudiness formation [7] }\end{array}$ & \\
\hline & Wine [12] & $\begin{array}{l}\text { High acetoin level } \\
\text { [12] }\end{array}$ & Flocculent sediment [11] & \\
\hline \multirow[t]{2}{*}{ Candida tropicalis } & $\begin{array}{l}\text { Fresh fruits: orange } \\
\text { (Citrus sinensis) and } \\
\text { pineapple (Ananas } \\
\text { comosus) [13] }\end{array}$ & & & $\begin{array}{l}\text { Candidiasis } \\
\text { has not been } \\
\text { transmitted } \\
\text { by food } \\
\text { products [5] }\end{array}$ \\
\hline & $\begin{array}{l}\text { Grated raw carrots } \\
{[14]}\end{array}$ & $\mathrm{CO}_{2}[14]$ & $\begin{array}{l}\text { Increase in exudate and } \\
\text { softening [14] }\end{array}$ & \\
\hline
\end{tabular}




\begin{tabular}{|c|c|c|c|c|}
\hline Yeast species & Food product & Spoilage compounds & Effect observed & Health hazard \\
\hline \multirow{3}{*}{$\begin{array}{l}\text { Hanseniasporal } \\
\text { Kloeckera }\end{array}$} & Fresh must [15] & & & \\
\hline & $\begin{array}{l}\text { Various storage } \\
\text { products [2] }\end{array}$ & $\begin{array}{l}\text { Low ethanol } \\
\text { concentration [2] }\end{array}$ & $\begin{array}{l}\text { Undesirable fermentation } \\
\text { products [2] }\end{array}$ & \\
\hline & $\begin{array}{l}\text { Must under } \\
\text { fermentation [7] }\end{array}$ & $\begin{array}{l}\text { Acetate production } \\
\text { [7] }\end{array}$ & $\begin{array}{l}\text { Aroma modification at } \\
\text { early fermentation stage in } \\
\text { winemaking [7] }\end{array}$ & \\
\hline
\end{tabular}

Table 1. Some of the most common yeasts often found in grape, musts and wines that can be considered spoilage yeast species in a wide range of food products.

with the novelty of their application in winemaking industry. A brief review of monitoring techniques as a tool for improving quality control in the winery is also included.

\section{Technologies for spoilage yeast control}

\subsection{Early technologies}

In the food industry, the control of the spoilage and pathogenic microorganisms was traditionally carried out by means of using thermal processes, to ensure the partial or total elimination of the microflora present $[17,18]$. Together with an aseptic and hermetic packaging, it was possible to effectively extend the shelf life of the food products ensuring at the same time its microbiological safety $[19,20]$. The main drawback of this kind of inactivation processes is the damage in organoleptic quality due to high processing temperatures. Another traditional way to fight against unwanted microorganisms is the addition of natural or chemically synthesized preservatives, such as organic acids (ascorbic, citric, benzoic, sorbic, etc.) and salts (potassium sorbate, sodium benzoate, sodium metabisulphite, etc.) [21, 22]. It is also possible to limit undesirable microbial development by modifying certain environmental parameters (temperature, $\mathrm{pH}$, water activity, nutrient availability, toxic compounds, etc.) during the production process in order to hinder its growth. In the field of oenology, the ethanol tolerance is believed to be one of the main factors limiting yeast growth [23]. In addition, some of the antimicrobials most commonly used in winemaking are sulphur dioxide $\left(\mathrm{SO}_{2}\right)$, dimethyl dicarbonate and sorbic acid.

Yeast species resistant to one preservative also tend to be resistant to others with similar chemical composition. Such is the case of benzoic acid, sorbic acid and sulphur dioxide [24]. Also, sorbic acid resistance has demonstrated to be highly correlated to ethanol resistance [25]. In general, yeast resistance to preservatives seems to be strain dependent and also dependent on the physiological characteristics of the cells $[6,26]$.

Sulphur dioxide $\left(\mathrm{SO}_{2}\right)$ is the chemical additive mainly used in wineries as antioxidant and preservative to control bacteria, moulds and spoilage yeasts [11,27] considering that its antiseptic property depends on the $\mathrm{pH}$ of the media [28]. However, in the last decades, its use is 
being reconsidered due to increasing allergic concerns. Researchers are looking for alternative methods to reduce the doses commonly added to grape juice and wine [29, 30].

High doses of $\mathrm{SO}_{2}$ are needed to control the growth of Dekkera bruxellensis in red wine. Barata et al. [23] suggested an average value of $1 \mathrm{mg} / \mathrm{L}$ molecular sulphur dioxide to prevent $D$. bruxellensis development during red wine maturation in oak barrels. Similarly, Saccharomycodes ludwigii and Zygosaccharomyces bailii have a strong resistance to $\mathrm{SO}_{2}$ and, in addition, Z. bailii also to organic acids [24].

Due to long-term exposure to $\mathrm{SO}_{2}$, some wine yeasts have developed certain defence mechanisms to fight against this antimicrobial [28]. The ability of Brettanomyces bruxellensis to enter a viable but not culturable (VBNC) state as a survival strategy induced by the presence of $\mathrm{SO}_{2}$ has been proved [31]. Molecular $\mathrm{SO}_{2}$ levels as low as $0.2-0.4 \mathrm{mg} / \mathrm{L}$ can induce the VBNC cells in different B. bruxellensis strains (tested in a synthetic wine medium) [32]. However, the metabolism of this spoilage yeast is maintained, so synthesis and release of volatile phenols continues even under this non-reproductive state [32]. Benito et al. [33] claimed that $20 \mathrm{mg} / \mathrm{L}$ of free $\mathrm{SO}_{2}$ is the minimum concentration required for inhibiting the enzymatic activity of $B$. bruxellensis at $\mathrm{pH} 3.5$.

Dimethyl dicarbonate (DMDC) is a dimethyl ester of dicarbonic acid used as cold sterilant in food industry. It is legally authorized in the USA [34], Australia [35] and Europe [36] as chemical preservative for ensuring the microbiological stability of wines. DMDC antimicrobial effectiveness is maximal at low $\mathrm{pH}$, high ethanol content and low microbial population [37]. At permissible usage levels, DMDC is more effective against yeast than bacteria or moulds [38]. The main mechanism of action of DMDC is to inactivate cellular enzymes such as glyceraldehyde-3-phosphate dehydrogenase and alcohol dehydrogenase through reaction with nucleophilic groups (imidazoles, amines and thiols) [39]. DMDC can be used to prevent spoilage yeasts growth in wines [40] as well as to stop alcoholic fermentation in the production of sweet wines [41] or to disinfect musts by removing native flora present [42].

In relation to their specific effect on spoilage yeasts, Z. bailii, S. ludwigii and Lachancea thermotolerans were found to be very sensitive to DMDC; complete cell death (initial population of $10^{6} \mathrm{CFU} / \mathrm{mL}$ ) can be achieved with a dose of 100-200 mg/L DMDC when added to red wine (12\% v/v and $\mathrm{pH}$ 3.5) [43]. Later experiments carried by Zuehlke et al. [44] confirmed the toxicity of DMDC against Z. bailii. On the contrary, Schizosaccharomyces pombe and Saccharomyces cerevisiae can survive in the presence of higher concentrations of DMDC (minimum inhibitory concentration (MIC) of $\geq 300 \mathrm{mg} / \mathrm{L}$ ). Moreover, the addition of DMDC in wines at the maximum dose legally permitted in Europe $(200 \mathrm{mg} / \mathrm{L} ;[36])$ was proved to be ineffective against lactic acid and acetic acid bacteria [43]. However, resistance to DMDC highly depends on the media composition, since the amount needed to inhibit Z. bailii and S. ludwigii $\left(10^{6}\right.$ cells $\left./ \mathrm{mL}\right)$ when DMDC is added to grape must is higher, around $400 \mathrm{mg} / \mathrm{L}$ [42]. Based on the different yeast sensitivity towards DMDC, the use of this compound could be suggested as a technology to favour the microbial development of certain yeast species during the initial stages of alcoholic fermentation. The dominance of the selected yeast can be ensured if the inoculum is added $12 \mathrm{~h}$ after grape must treatment with DMDC [42]. 
Its use before the end of fermentations is not recommended since the antimicrobial effect of DMDC can be also exerted against the fermenting species such as S. cerevisiae and Oenococcus oeni [40]. These same authors stated that the action of DMDC added during vinification has a transitory nature, so the preservation effect does not last with time and a fractional dosage might be needed, especially if the goal is to protect the wine during barrel maturation [45].

There also exists a synergistic activity to increase the inactivation effect against wine yeast and bacteria between DMDC and sulphur dioxide in both potassium and sodium metabisulphite salts [40,43]. In this regard, the use of DMDC allows a significant reduction of sulphur content in grape juice and semi-sweet wines [46].

Regarding health issues, DMDC does not represent any threat since it is naturally, rapidly and completely hydrolysed to methanol and carbon dioxide in aqueous solutions [46]. Notwithstanding, a disadvantage of the use of DMDC in winemaking is its potential toxicity during handling [39].

With relation to the use of weak acids, benzoic and sorbic acids are able to control spoilage yeasts in wines when used in certain concentrations. The lipophilic character of benzoic and sorbic acids allows their diffusion in its undissociated form through cell membranes [24]. However, so far, benzoic acid is not authorized for use in wine [47].

Z. bailii is a wine spoilage yeast species highly resistant to commonly used preservatives such as benzoic and sorbic acids [48]. Similarly, Zygosaccharomyces rouxii is an osmophilic yeast responsible for spoilage in high sugar content beverages. Among the chemical compounds with antimicrobial properties used in food products, potassium sorbate, sodium benzoate, dimethyl dicarbonate and vanillin showed good results to control the growth of Z. rouxii in concentrated grape juice [26]. After applying a mathematical model, a maximum inhibitory effect with average growth reduction of $40 \%$ was estimated using each of the four preservatives alone with the following doses: potassium sorbate $(>4.7 \mathrm{mM})$, sodium benzoate $(>10.4$ $\mathrm{mM})$, dimethyl dicarbonate $(>1 \mathrm{mM})$ and vanillin $(>30 \mathrm{mM})$.

B. bruxellensis has also a strong resistance to benzoic and sorbic acids. The required sorbic acid dose to arrest its growth and its enzymatic activity exceeds long the legal limit in wine $(250 \mathrm{mg} / \mathrm{L})$ [33]. And as it was previously mentioned, benzoic acid is still forbidden as wine additive. According to Loureiro and Malfeito-Ferreira [49], B. bruxellensis can stand up to 950 $\mathrm{mg} / \mathrm{L}$ of sorbic acid at $\mathrm{pH} 3.5$.

Among the physicochemical parameters that can be handled in the cellar, the storage temperature and the level of ethanol in wine together can exert a synergistic limiting effect on the growth of the wine spoilage yeast $B$. bruxellensis. The optimal combination range of both parameters to halt the proliferation of these microorganisms is above $14 \% \mathrm{v} / \mathrm{v}$ ethanol content and below $12^{\circ} \mathrm{C}$ storage temperature [50]. Similarly, trials in synthetic media revealed that $D$. bruxellensis proliferation can be hindered by ethanol concentrations above $14.5-15.0 \%(\mathrm{v} / \mathrm{v})$ [23]. According to Couto et al. [51], the temperature-time binomial necessary for the thermal destruction of Dekkera/Brettanomyces yeast cells largely depends on the ethanol and phenolic contents, particularly ferulic acid, of the wine. Significant reductions in population of contaminated wine samples (initial inoculum of approximately $1 \times 10^{7} \mathrm{CFU} \mathrm{mL}^{-1}$ ) can be achieved with temperatures above $35^{\circ} \mathrm{C}$. It is worth mentioning that $B$. bruxellensis behaves differently in 
white and red wines, showing less development in white wines [23]. In addition, $\mathrm{SO}_{2}$ requirements may be reduced with low storage temperatures, as the optimal growth temperature for Brettanomyces is $25-28^{\circ} \mathrm{C}$ [52]. These authors provided a limiting range of below $15^{\circ} \mathrm{C}$ and above $0.4 \mathrm{mg} / \mathrm{L}$ molecular $\mathrm{SO}_{2}$ for controlling spoilage by Brettanomyces in stored red wines, although complete eradication cannot be ensured with these conditions.

\subsection{Emerging technologies}

\subsubsection{High hydrostatic pressure}

The high hydrostatic pressure (HHP) treatment is a non-thermal process used to inhibit pathogenic microorganisms including spoilage microbes as well as enzymes [53]. According to these authors, the food products that are treated do not change nutritional or modify their sensory quality. The HHP uses pressure-transmitting liquids (water, ethanol solutions, sodium benzoate solutions, etc.) to homogeneously transfer pressure to the food sample [54]; the process may be batch, semi-continuous or continuous. The use of HHP is also expected to increase the shelf life [55] of a wide range of food products able to be treated including meat, eggs, vegetables, seafood [53], fruits such as sweet cherries [56] or mango pulp [57], juices [55, 58] and Serrano ham [59], among others.

In the winemaking industry, the HHPs have been used to reduce or inhibit the presence of spoilage yeasts such as B. bruxellensis. In this matter, Van Wyk and Silva [60] have used $200 \mathrm{MPa}$ for 3 min achieving a reduction of up to $5.8 \log$ but higher than $6 \log$ when increasing the pressure to $400 \mathrm{MPa}$ during a much shorter period of time ( $5 \mathrm{seg}$ ). These parameters were also evaluated by González-Arenzana et al. [61] but also considering $\mathrm{pH}$ and amount of ethanol in wines; high ethanol and high $\mathrm{pH}$ needed less pressure (100 MPa) to inactivate B. bruxellensis cells, while at lower ethanol and lower $\mathrm{pH}$ the pressure used was higher (200 MPa). The HHP could also be used as a treatment for grapes in order to reduce wild yeast populations in order to be able to use yeast starters [62]; HHP has shown to increase pigment extraction and ethanol and methanol increase in wines after treatment. In the case of beer pasteurization, the use of $600 \mathrm{MPa}$ allows beer with different ethanol content to have more than $7 \log$ reductions of $S$. cerevisiae within $5 \mathrm{~s}$ [63].

\subsubsection{Pulsed light irradiation}

The pulsed light irradiation is a technique used to inactivate microorganisms in food products. The pulses are stored electricity in UV lamps that do not contain mercury but xenon [64], released in very short periods of time (fractions of millionths or thousandths of a second) that are rich in UV-C light (from 200 to $280 \mathrm{~nm}$ in the spectrum) [65]. This sterilization technique can cause DNA damage in the same way that continuous UV light does, nonetheless irradiation with pulsed light may also induce distortion in cell membranes and vacuoles [66]; therefore, the pulsed light irradiation may be considered an improved version of the UV treatment [64].

Pulsed light has been evaluated in the last decade as an efficient technique against foodborne spoilage microorganisms in commercial and fresh fruit juices using pulsed light against $S$. cerevisiae and pathogenic bacteria [67], or apple juices [68] where the combination of pulsed 
light with ultrasound has been evaluated as an alternative to inactivate S. cerevisiae: fresh strawberries [69] with reductions of 1 log colonies of yeast and microfungi lengthening shelf life 2 days; cured meat products [70] against pathogenic bacteria. Nevertheless, there are studies on the use of pulsed light on several food products; in wine or in the winemaking industry the evaluation of this technique appears to be scarce. The use of pulsed light might not be limited to just inactivating spoilage yeast in grapes and musts but also as a technique to potentially improve polyphenols extraction during maceration, thus increasing pigment compounds in wine.

\subsubsection{Electric pulses}

The electric pulses (EPs) are a method used for food preservation that avoids the use of chemical compounds as well as the use of thermal treatments [71]. Thus, it can be considered a cold temperature treatment that may preserve foodborne properties.

Hülsheger et al. [72] demonstrated that EPs have different effect on microorganisms. Yeasts and Gram-positive bacteria are more resistant than Gram-negative bacteria to the disruption caused by cellular structures by low-energy pulses while most of the microorganisms $(>99 \%)$ die with high-energy pulses. The colonies were also more susceptible to die at logarithmic growth phase than when in steady state. Besides the growth phase, Gáskovà et al. [73] have shown that there are other factors involved in the efficiency of electric pulses for killing yeasts; such factors include the amplitude and the duration of the pulses, the size of the yeast cells and the temperature and conductivity of the media where the yeasts grow.

Electric pulses have been used lately in the production of fruit juices for its efficacy in microbial reduction and for keeping their sensorial and nutritional properties [74]. The use of EP to eliminate spoilage yeasts such as $S$. cerevisiae in orange juice requires less intensity pulses than those to inactivate other pathogens microorganisms such as the bacteria Escherichia coli or Listeria innocua [75].

The effect of EP could be combined with the use of other antimicrobial technology like the lyticase digestion; the combined effect of both techniques may be a biotechnological application for spoilage yeast control since the use of mild EP $(2-4.5 \mathrm{kV} / \mathrm{cm})$ affects the cell-wall porosity and therefore lower doses of lyticase are needed to effectively inactive S. carlsbergensis, Kluyveromyces lactis and K. marxianus [76].

Biotechnology applications of the electric pulses or the electroporation, other than spoilage yeasts control, may include genetic transformation of cells by incorporation of foreign DNA, extraction of intracellular metabolites and biomass drying [71].

\subsubsection{Natural extracts}

The use of antimicrobials extracted from nature such as chitosan, essential oils (active ingredients: eugenol, allicin, carvacrol, thymol and limonene), spices or nisin is very widespread in food preservation [21], but the limits of its antifungal activity and their potential applications as winemaking additives remain to be further explored. 
Chitosan ( $\beta$-1,4-D-glucosamine) is a linear heteropolysaccharide obtained by deacetylation of chitin. The high density of amino groups present in its structure makes chitosan a bioactive polymer [77]. This polysaccharide with antimicrobial activity is found in nature being part of the exoskeletons of arthropods, diatoms and algae, and the cell wall of some fungi (particularly zygomycetes) [78]. In a study carried out by Rojo et al. [26], where a dose of $300 \mathrm{mg} / \mathrm{L}$ of chitosan was added to a high sugar culture media in order to assess its inhibition properties to control the wine spoilage yeast $Z$. rouxii, it was found that with such a high dose of chitosan, tripling the allowable dose in wines $(100 \mathrm{mg} / \mathrm{L})$, no inhibition effect exists. Previously, $Z$. rouxii had been already reported as sensitive yeast to chitosan (completely inactivated by $100-400 \mathrm{mg} / \mathrm{L}$ ), but this result was only based on the study of one strain isolated from a spoiled carbonated beverage [79]. Similarly, S. ludwigii has been identified as yeast very resistant to chitosan ( $5 \mathrm{~g} / \mathrm{L}$ of chitosan was required to inactivate $S$. ludwigii). The minimum inhibitory concentration for Brettanomyces/Dekkera ranges from 0.2 to $0.5 \mathrm{mg} / \mathrm{mL}$ of chitosan, depending on the molecular weight [80]. Low-molecular-weight chitosan has higher antifungal properties. With respect to impact on sensory quality, the addition of chitosan may adversely affect the colour of the wine, mainly through a reduction of the colour intensity [80]. Moreover, Gómez-Rivas et al. [77] observed that in mixed fermentations B. bruxellensis and B. intermedius are more sensitive to chitosan than S. cerevisiae. Taillandier et al. [81] have also tested the use of chitosan of fungal origin to control B. bruxellensis in winemaking and concluded that its mechanism of action is a complex combination of both physical adsorption on cell wall and the biological interaction by changing permeability of cell membrane, together with an observed effect on the growing rate and the physiological state of B. bruxellensis. Petrova et al. [82] also reported on the efficacy of chitosan as strategy to control $B$. bruxellensis development in red wines, with an average reduction of 3 logs in the culturability. It has been proved that when applied in the vineyard chitosan can act as an inducer of the plant defence system, mainly by enhancing the polyphenolic phytoalexins synthesis, and therefore it represents a useful protection treatment against powdery mildew infection [83]. Chitosan can be also used as natamycin carrier to protect the cheese surface from fungal contamination and thus extend its shelf life [84]. It is also possible to use microencapsulation techniques with chitosan to dose oily compounds, such as essential oils, with the additional advantage of protecting the active ingredient (e.g. limonene) and thus preserving its antimicrobial properties [85].

S. cerevisiae has demonstrated strong resistant to chitosan, doses above $2 \mathrm{~g} / \mathrm{L}$ are needed to fully inhibit it. Conversely, B. bruxellensis seems to be very susceptible to this natural extract, $0.2 \mathrm{~g} / \mathrm{L}$ can effectively inactivate it. Hanseniaspora uvarum and Z. bailii, other spoilage wine yeasts, can be also inhibited by chitosan with $0.4 \mathrm{~g} / \mathrm{L}$ [86]. However, all these results correspond to growth inhibition assays in laboratory media. As expected, these authors observed that the antimicrobial effect of chitosan is less under winemaking conditions. Regarding the performance of alcoholic fermentation, a slight delay in the beginning of the fermentation was observed, but without major repercussions [86].

Among the essential oils extracted from plants, those from cinnamon, clove, garlic, onion, oregano and thyme are the inhibitoriest against food spoilage yeasts [87]. Antimicrobial activity of these compounds is well documented [88]. 
Eugenol is the main component of clove oil ( $\approx 85 \%)$. So far, eugenol has proven to be effective as antibacterial and antifungal in several food products [89]. Both eugenol and thymol act on the membrane and cell wall, causing cell lysis [90]. These same authors suggested the use of eugenol and thymol as lysing agents to extract the genomic DNA from yeast cell instead of using zymolyase and sodium dodecyl sulphate (SDS). However, according to Kubo et al. [91] eugenol alone may not respond as effective antimicrobial against Z. bailii and S. cerevisiae, since the concentration required for ensuring the fungicidal effect is quite high $(800 \mu \mathrm{g} / \mathrm{mL})$.

Carvacrol and thymol are phenolic compounds being part of the essential oil from oregano and thyme [92]. According to Chavan and Tupe [93], low concentrations of carvacrol and thymol ( $\leq 64 \mathrm{mg} / \mathrm{L}$; used independently) are effective in limiting the growth of several wine spoilage yeasts, including Metschnikowia pulcherrima, Z. rouxii, S. pombe, Debaryomyces hansenii and D. bruxellensis. Results for minimum inhibitory concentration values were comparable or even better than those of potassium metabisulphite. The antifungal mechanism of these two essential oils' active ingredients is based on the membrane damage and leakage of cytoplasmic content, thus increasing permeability.

As for allicin (diallyl thiosulphinate), it is the main bioactive component of garlic extract [94]. It is well known for its antioxidant, antibacterial and antifungal activities [95] and also for its anticancer activity $[96,97]$. The main mechanism involved in the antimicrobial effect of allicin is based on its rapid reaction with thiol-containing proteins [94]. Thus, allicin can regulate the activity of enzymes containing very reactive or unshielded $\mathrm{SH}$ groups. With relation to its potent antifungal properties, allicin is effective against a wide range of yeasts, among them $S$. pombe, S. cerevisiae [98], Aspergillus spp. [99] and Candida spp. [100]. It also affects the synthesis of mycotoxins and inhibits the germination of spores as well as the growth of the hyphae [100]. Yoshida et al. [98] set the minimum inhibitory concentration (MIC) of allicin in $5 \mathrm{mg} /$ $\mathrm{mL}$ for S. pombe and $10 \mathrm{mg} / \mathrm{mL}$ for S. cerevisiae. Moreover, chitosan and garlic extract, used independently, have also shown promising results as treatments for the control of fungal diseases of the vine due to pruning [101]. In the medical field, allicin and its derivatives have been proposed as antifungal prophylactic due to their strong efficacy in inhibiting microbial development [102]. However, further studies are still required to confirm the potential therapeutic use of allicin [103].

Despite their interesting antimicrobial properties, there still exist some limitations to the use of some of these natural extracts such as their solubility in water, their susceptibility to oxidation (part of its effectiveness is lost) and the impact on sensory attributes [21]. A possible solution to the low water solubility of some natural extracts is their transformation into nanoemulsions [104, 105] or the use of nanoencapsulation techniques to protect their antimicrobial properties [106].

The inhibition activity on the growth of some wine spoilage yeasts using different antimicrobial compounds was measured by agar diffusion tests (Figure 2). The dark areas around the disks suggest the inhibitory effect in growing colonies, thus demonstrating their effectiveness. This assay can be used to assess the susceptibility of the yeast species to each of the antimicrobials, taking into account the limitations due to the diffusion properties of the antifungal compounds in solid media. 

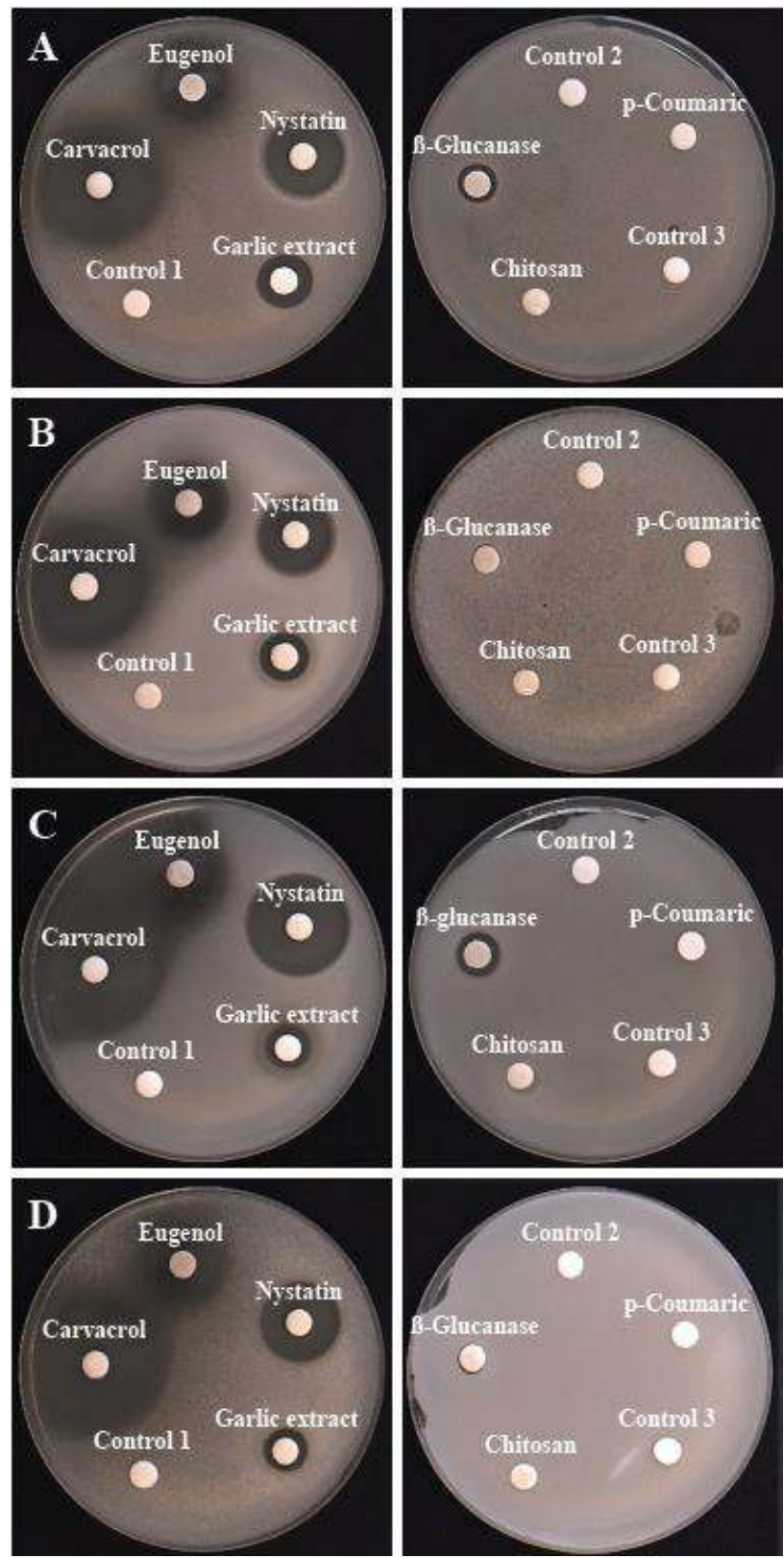

Figure 2. Agar diffusion tests for antimicrobial screening. Antimicrobials tested: eugenol, carvacrol, nystatin (antibiotic), garlic extract (allicin), chitosan, $\beta$-glucanase and $p$-coumaric acid. Controls used for the preparation of the antimicrobials: control 1-water, control 2-ethanol and control 3-acetic acid. Yeast species tested: (A) S. ludwigii, (B) D. bruxellensis, (C) P. anomala and (D) Z. rouxii. 
Despite their interesting antimicrobial properties, there still exist some limitations to the use of some of these natural extracts such as their solubility in water and the impact on sensory attributes [21].

\subsubsection{Antimicrobial peptides}

Antimicrobial peptides are important molecules naturally occurring in the immune system [107] and may have different amino acids conformation. Their importance as antimicrobial agents increased when bacteria and other pathogens became more resistant to drugs [108]. Among the most studied peptides are tritrpticin and indolicidin, related cathelicidins [109] rich in Arg and Trp residues [110] as well as the lactoferricin. Other peptides having microbicidal activity are cecropins, defensins, magainins, melittin and alamethicin [111].

Tritrpticin is a positively charged peptide with tryptophan (Trp) residues [112] that has antifungal activity besides having antibacterial activity against Gram-positive and Gram-negative bacteria [113, 114]; it is naturally found in granules of bovine and porcine neutrophils [115] as well as in insects $[107,116,117]$. The electrostatic interaction between the cationic residue and the negative charge of phospholipids in the membrane has been recognized as an important factor in the microbicidal action found in these biomolecules [118].

Indolicidin is another peptide with antimicrobial activity against both fungi and bacteria (Gram-positive and Gram-negative) [119]. Similar to tritrpticin, indolicidin is a tryptophan (Trp)-rich peptide [120] that also contains proline (Pro) residues in its configuration [121]; its structure resembles that of detergent micelles and of phospholipid vesicles [122]. It has been isolated from cytoplasmic granules of bovine neutrophils [123] but it is also present in humans and other mammals as well as in some primitive vertebrates [124]. It acts directly on the lipidic bilayer [125] causing disruption in the cell membrane.

Lactoferricin B (Lfcin B) is a peptide obtained during the gastric digestion of the bovine protein lactoferrin [126]. Despite the fact that other mammals including humans also produce lactoferricins, the Lfcin B has higher antimicrobial potency [127]. Lfcin B shows different properties including antibacterial, antifungal, antiviral, antitumour, anti-inflammatory and immunoregulatory [127].

Antimicrobial peptides are important for the control of spoilage yeasts in food products. Lfcin B derivatives reduce spoilage yeasts such as D. bruxellensis [128] and Z. bailii and Z. bisporus [129] in wine production. Peptides are used to control the most common spoilage yeasts in dairy products such as K. marxianus, D. hansenii, Candida spp. and other spoilage yeasts such as Zygosaccharomyces microellipsoides, Rhodotorula mucilaginosa, Yarrowia lipolytica, Torulospora and Pichia [130]. Mozzarella cheese packaged with films of chitosan with up to $60 \%$ lysozyme has antimicrobial activity against yeast Pseudomonas fluorescens and other bacteria and moulds [131].

In medical applications, indolicidin has antimicrobial activity against different pathogens such as yeasts, viruses, bacteria, fungi and protozoa [132]. Indolicidin has been tested against candidiasis produced by fungi Candida albicans [133], and nosocomial pathogen yeasts Candida krusei and Candida parapsilosis [134] responsible for bloodstream infections 
[109]. It is also known that indolicidin directly binds DNA forming a complex with the catalytic HIV-1 integrase [124] producing inhibitory activity in it with an implication on the HIV virus replication cycle [135]. Lfcin B has fungicidal activity against the pathogenic yeast Candida tropicalis and fungicidal properties against the fungi Candida neoformans and C. albicans [136].

A drawback in the use of some antimicrobial peptides like tritrpticin and indolicidin for treatment of infectious diseases produced by pathogen agents is the hemolytic activity observed against blood hematocytes [113, 115, 132]; therefore, it is important to use alternative antimicrobial peptides with less toxicity in immunocompromised patients [133].

\subsubsection{Killer toxins and $\beta$-glucanases}

Killer toxins are known as pore proteins produced by yeast metabolism and are able to kill sensitive yeast cells by forming cell wall or cell membrane disruptions [137]. There are different killer toxins produced by either Saccharomyces and non-Saccharomyces yeasts used as antimicrobials.

Among the toxins produced by non-Saccharomyces, Tdkt is produced by the species Torulaspora delbrueckii with $\beta$-glucanase and chitinase activity against yeasts B. bruxellensis, Pichia guilliermondii, Peronospora manshurica and Pichia membranaefaciens [138]; toxin Kwkt is obtained from the species Kluyveromyces wickerhamii and toxin Pikt is produced by the species Wickerhamomyces anomalus (formerly Pichia anomala), both are used against spoilage yeasts Brettanomyces/Dekkera [139]; toxin Kpkt is produced by the species Tetrapisispora phaffii and it could be used to control spoilage yeasts in winemaking [140] since it has proven fungicidal activity against yeast Hanseniaspora/Kloeckera [141]. This last yeast is also used as killer yeast against some fungal pathogens in plants and also to fight infections produced by fungi in animals and humans due to its high $\beta$-1,3-glucanase activity producing disruptions in the cell wall [142].

S. cerevisiae has also shown the ability to produce killer toxins; four different killer yeasts from this species produce killer toxins K1, K2, K28 and Klus. These yeasts are able to produce the toxins during spontaneous wine fermentation as the population of other yeasts decreases [143]. The killer toxin K1, for example, having the glycosylated subunits $\alpha$ and $\beta$, is released out of the cytoplasm [144]. The killer toxin forms a channel in the membrane of target cells through which ions are conducted to the exterior producing cellular death. The activity observed in some killer toxins is due to $\beta$-glucanases, which has been used to produce a synthetic $\beta$-glucanases preparation as antibacterial material against yeasts $D$. bruxellensis and Z. bailii [145]. The effect of $\beta$-glucanases on the cell integrity can be observed in Figure 3 where cells of the species $S$. ludwigii have been disrupted after the addition of two different $\beta$-glucanases.

Even though both compounds have same disruptive inhibition mechanism, the activity of the $\beta$-glucanases is not the same. Such an activity is compared in Figure 4 where YPD liquid growing media have been inoculated with four different wine spoilage yeasts: S. ludwigii, $D$. bruxellensis, $P$. anomala and Z. rouxii. The media where $\beta$-glucanase II has been used did not show any growth indicating total effectiveness of the treatment, while the media where 

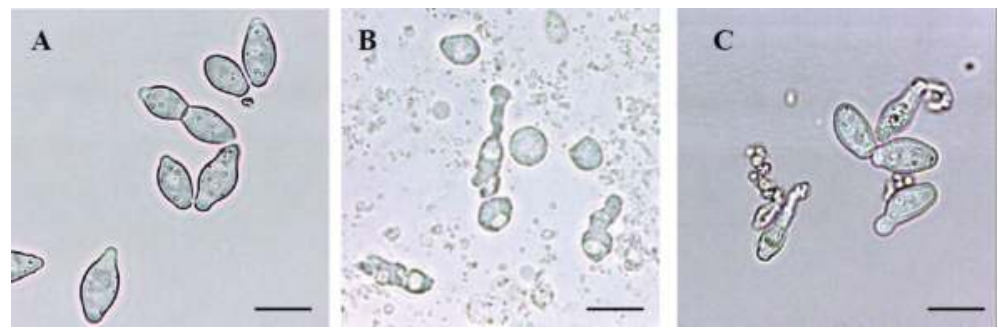

Figure 3. Effect of $\beta$-glucanases on the yeast's cell wall after the addition of $\beta$-glucanase I (B) and $\beta$-glucanase II (C) to $S$. ludwigii (A). Bar scale $10 \mu \mathrm{m}$.
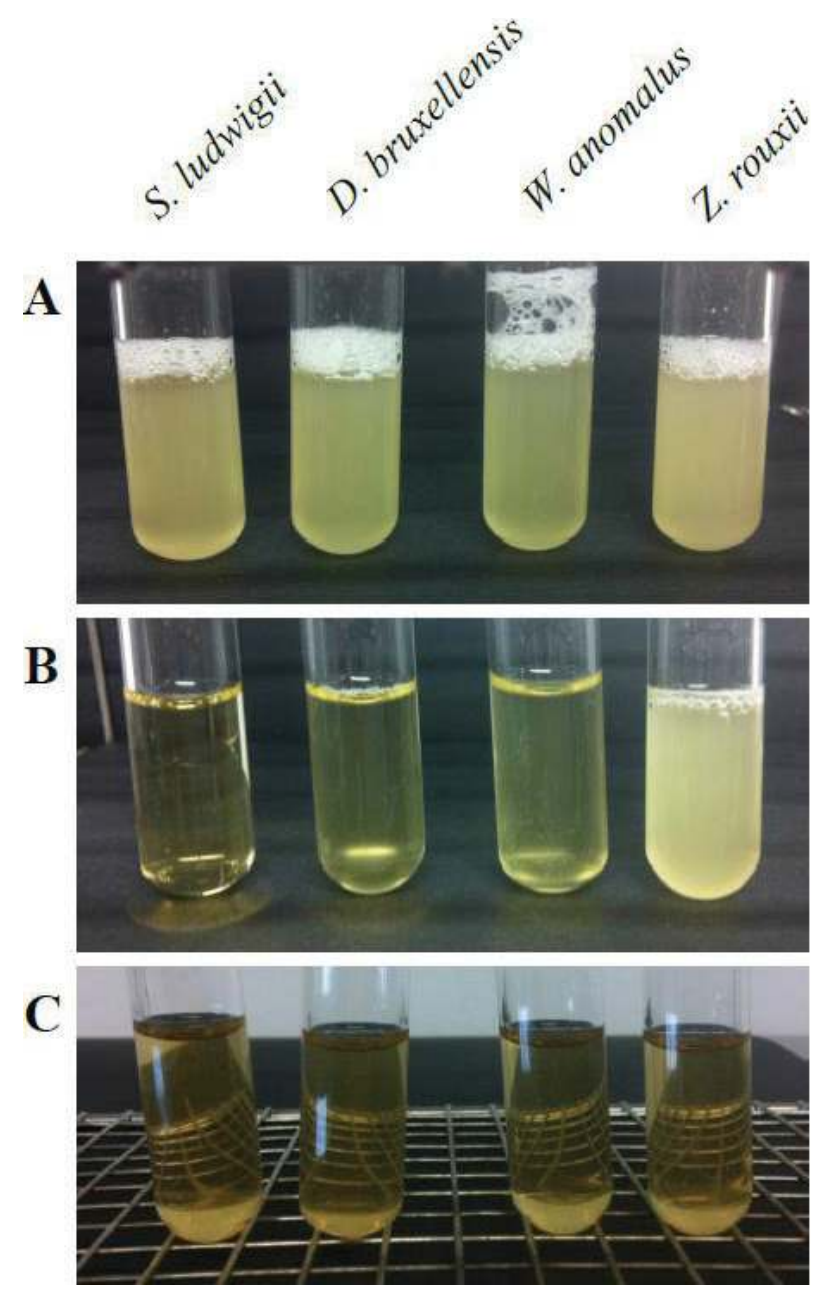

Figure 4. Comparison of the effect of two $\beta$-glucanases in YPD liquid growing media with same optical density (OD) of S. ludwigii, D. bruxellensis, P. anomala and Z. rouxii. The trials are grouped in (A) control, (B) $\beta$-glucanase I and (C) $\beta$-glucanase II. 
$\beta$-glucanase I has been added showed $\mathrm{CO}_{2}$ production and turbidity formation in function of the sensibility of each yeast species. Wine spoilage yeast $S$. ludwigii appears sensitive to both $\beta$-glucanases, as no foam has been formed after the addition of either compound.

In the case of $\beta$-glucanase, the inhibition zone observed in the agar plates suggests a low diffusion ability and thus limited antimicrobial activity; however, when grown in liquid media in the presence of same $\beta$-glucanase all the spoilage yeasts showed sensitivity (see Figure 2).

The yeasts could be neutral or sensitive to toxins produced by killer yeasts. In this matter, [146] have shown that the yeast species B. bruxellensis, B. anomalus, D. anomala, B. custerisanus, H. uvarum, S. cerevisiae and Z. bailii have either sensitive or neutral nature towards killer toxins produced by the species K. wickerhamii and C. pyralidae. Santos et al. [147] have also described the resistance of the species S. cerevisiae to the toxin CYC 1410 produced by the species Ustilago maydis during wine production; therefore, this procedure could inhibit the implantation of $B$. bruxellensis spoilage yeast. Cytoplasmatic $\beta$-glucanases have also shown, on the other hand, interesting contribution to wine-sensory properties as polysaccharides are released from the autolysis of non-Saccharomyces yeast cells during wine production [148]. Polysaccharides can improve mouth-feel properties of wines by changing their viscosity.

A summary of certain emerging antifungal compounds is presented in Figure 5.

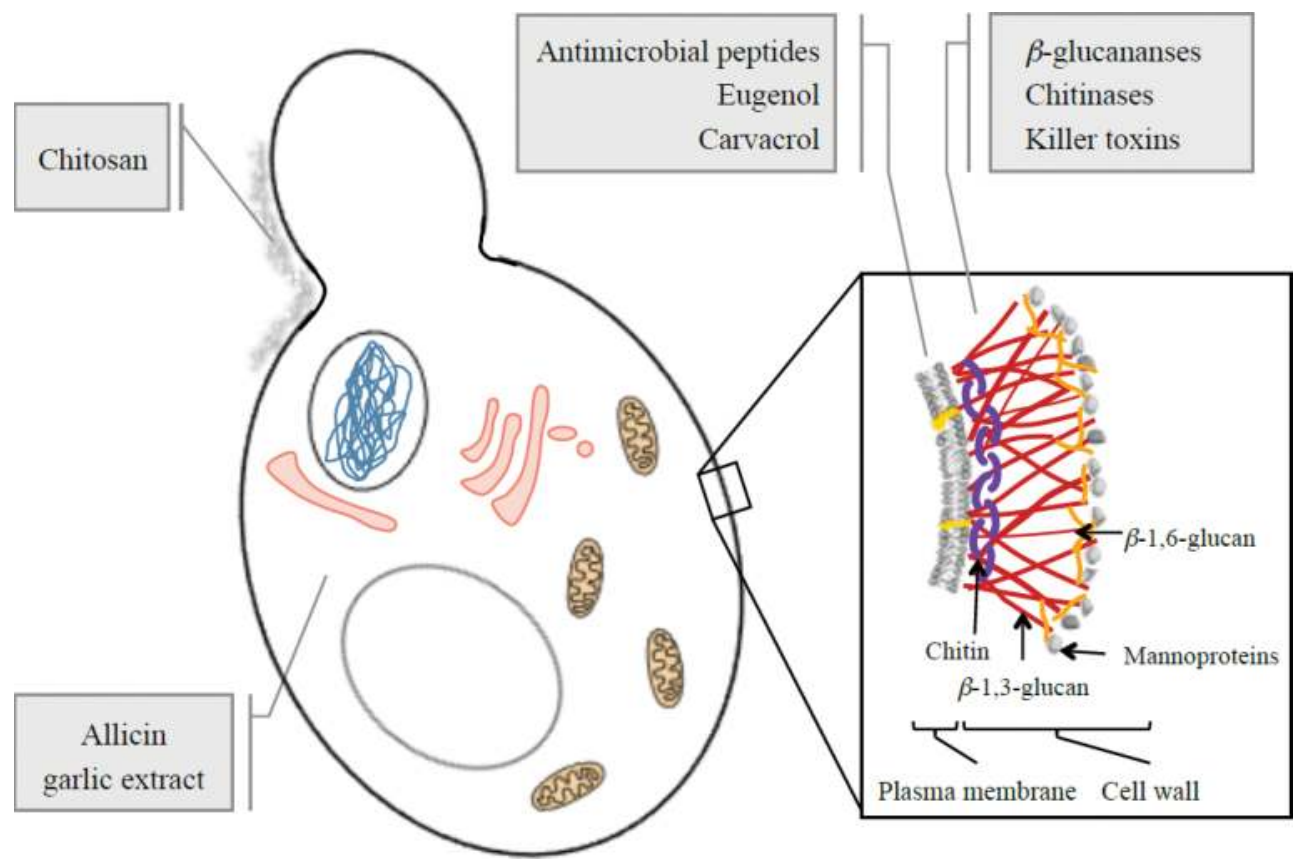

Figure 5. Schematic representation of the main mechanisms involved in the antimicrobial effect of different compounds on a yeast cell. The arrows indicate the target of each compound in the yeast structure: Plasma membrane (antimicrobial peptides, eugenol and carvacrol), cell wall ( $\beta$-glucanases, chitinases and killer toxins), endoplasmatic enzymes (allicin) and physical adsorption on cell wall (chitosan). 


\section{Yeast populations monitoring techniques}

Parallel to the use of technologies that reduce the colonization of spoilage yeasts in food products, there are technologies able to monitor the yeasts and bacteria populations and their nature in the alcoholic and malolactic fermentations during wine production. One of these techniques is the flow cytometry (FCM) [149]; other techniques are fluorescence-activated cell sorting (FACS), quantum dots (QDs) and emerging monitoring technologies such as mass cytometry (Cy-TOF), imaging flow cytometry and, recently, spectral cytometry.

FCM, used for counts of microorganism populations in wine, allowed the simultaneous determination of yeasts for as low as $10^{3}$ cells $/ \mathrm{mL}$ and, despite its size, populations of malolactic bacteria higher than $10^{4}$ cells/mL [150]. FCM is able to show real-time situation of microorganisms in different matrices although it is considered complicated implementation due to the cost of reagents and the need of recruiting trained staff. FCM that relies on the use of complementary fluorescence dying to selectively determine specific type of microorganisms [151] through, for example, the metabolic enzyme activity or antigen expression is known as fluorescence-activated cell sorting (FACS). This technology is useful in monitoring changes in yeast cellular organelles' biogenesis such as the mitochondria [152].

The QD is a technology based on the production of semiconductor nanoparticles made from cadmium salts crystals with chloride $(\mathrm{Cl})$, tellurium $(\mathrm{Te})$ and sulphide $(\mathrm{S})$ by target microbial cells such as spoilage yeast [153]. These nanoparticles are used as biomarkers of nucleic acids and proteins and can be detected visually when they are excited by a light source. QDs are photostable and they have a wide range of absorption while they have a narrow emission peak [154].

Imaging flow cytometry has been used to compare the mode of action in which different killer toxins affect cell structures. Comitini et al. [140] saw that the toxin Kpkt from T. phaffii had different mode of action from that of the toxin $\mathrm{K} 1$ from S. cerevisiae; all yeast cells dead to toxin $\mathrm{K} 1$ after well-known membrane disruption forms potassium channels, have nucleic acids stained with propidium iodide (PI) while dead cells exposed to Kpkt are not all stained with PI. These results suggested a difference in the way that both toxins have to kill yeast cells. Flow cytometry analyses showed that Kpkt causes disruption in the cell-wall integrity due to very specific $\beta$-glucanase activity [15].

The spectral cytometry was developed as to increase the accuracy and the precision of flow cytometry results by a higher resolution obtained with spectral analysis from more discrete bands of emission of multiple stained samples [155] as in the case of microbial counts in foodborne matrices stained with PI. Spectral measurements combined with flow cytometry technique allow obtaining fluorescence and RAMAN spectra analysis of large particles in chemical and biological processes [156].

\section{Future trends}

Several antimicrobial techniques have been developed to control the presence of spoilage yeasts in food products through the years. These techniques aim to diminish the negative eco- 
nomic impact of having contaminated/spoiled products as well as the potential health threat that this may represent. Some of these techniques are already in use by the winemaking industry and others may be explored by the different process of stages from vine to bottled wine.

The trend observed is that the winemaking industry is targeting the use of innocuous control techniques to avoid spoilage yeasts during the entire process in order to preserve varietal aromas from grapes, to protect and to extend the anthocyanins extraction yield and, in the best-case scenario, to improve the overall quality of wines.

\section{Acknowledgements}

This work was funded by the INNTER WINARGAL 2015 project (CDTI-MINECO).

\section{Author details}

Carlos Escott ${ }^{1}$, Iris Loira ${ }^{1}$, Antonio Morata ${ }^{1 *}$, María Antonia Bañuelos ${ }^{2}$ and José Antonio Suárez-Lepe ${ }^{1}$

*Address all correspondence to: antonio.morata@upm.es

1 Department of Chemistry and Food Technology, Universidad Politécnica de Madrid, Madrid, Spain

2 Department of Biotechnology and Plant Biology, Universidad Politécnica de Madrid, Madrid, Spain

\section{References}

[1] Fleet G. The commercial and community significance of yeasts in food and beverage production. Yeasts in Food and Beverages. Springer-Verlag, Berlin Heidelberg; 2006. pp. 1-12

[2] Palpacelli V, Ciani M, Rosini G. Activity of different 'killer' yeasts on strains of yeast species undesirable in the food industry. FEMS Microbiology Letters. 1991;84(1):75-78

[3] Rojo MC, López FA, Lerena M, Mercado L, Torres A, Combina M. Effects of pH and sugar concentration in Zygosaccharomyces rouxii growth and time for spoilage in concentrated grape juice at isothermal and non-isothermal conditions. Food Microbiology. 2014;38:143-150

[4] Alonso A, Belda I, Santos A, Navascués E, Marquina D. Advances in the control of the spoilage caused by Zygosaccharomyces species on sweet wines and concentrated grape musts. Food Control. 2015;51:129-134

[5] Fleet G. Spoilage yeasts. Critical Reviews in Biotechnology. 1992;12(1-2):1-44 
[6] Martorell P, Stratford M, Steels H, Fernández-Espinar MT, Querol A. Physiological characterization of spoilage strains of Zygosaccharomyces bailii and Zygosaccharomyces rouxii isolated from high sugar environments. International Journal of Food Microbiology. 2007;114(2):234-242

[7] Loureiro V, Malfeito-Ferreira M. Spoilage yeasts in the wine industry. International Journal of Food Microbiology. 2003 Sep 1;86(1-2):23-50

[8] Fleet GH. Yeast interactions and wine flavour. International Journal of Food Microbiology. 2003;86(1):11-22

[9] Passoth V, Fredlund E, Druvefors UA, Schnurer J. Biotechnology, physiology and genetics of the yeast Pichia anomala. FEMS Yeast Research. 2006 Jan;6(1):3-13

[10] Schaffrath R, Breunig KD. Genetics and molecular physiology of the yeast Kluyveromyces lactis. Fungal Genetics and Biology. 2000;30(3):173-190

[11] Du Toit M, Pretorius IS. Microbial spoilage and preservation of wine: Using weapons from nature's own arsenal-A review. South African Journal of Enology and Viticulture. 2000;21(Special Issue):74-96

[12] Romano P, Suzzi G. Origin and production of acetoin during wine yeast fermentation. Applied and Environmental Microbiology. 1996 Feb;62(2):309-315

[13] Akinmusire O. Fungal species associated with the spoilage of some edible fruits in Maiduguri Northern Eastern Nigeria. Advances in Environmental Biology. 2011:157-162

[14] Babic I, Hilbert G, Nguyen-The C, Guiraud J. The yeast flora of stored ready-to-use carrots and their role in spoilage. International Journal of Food Science and Technology. 1992;27(4):473-484

[15] Ciani M, Fatichenti F. Killer toxin of Kluyveromyces phaffii DBVPG 6076 as a biopreservative agent to control apiculate wine yeasts. Applied Environmental Microbiology. 2001 Jul;67(7):3058-3063

[16] Gyawali R, Ibrahim SA. Natural products as antimicrobial agents. Food Control. 2014;46:412-429

[17] Török T, King A. Thermal inactivation kinetics of food-borne yeasts. Journal of Food Science. 1991;56(1):6-9

[18] Gaze J. Microbiological aspects of thermally processed foods. Journal of Applied Microbiology. 2005;98(6):1381-1386

[19] Hotchkiss J. Safety Considerations in Active Packaging. Active Food Packaging. Springer, US; 1995. pp. 238-255

[20] Brody AL, Bugusu B, Han JH, Sand CK, McHugh TH. Innovative food packaging solutions. Journal of Food Science. 2008;73(8):R107-R116

[21] Raybaudi-Massilia RM, Mosqueda-Melgar J, Soliva-Fortuny R, Martín-Belloso O. Control of pathogenic and spoilage microorganisms in fresh-cut fruits and fruit juices 
by traditional and alternative natural antimicrobials. Comprehensive Reviews in Food Science and Food Safety. 2009;8(3):157-180

[22] Davidson PM, Taylor TM, Schmidt SE. Chemical Preservatives and Natural Antimicrobial Compounds. In: Food microbiology. American Society of Microbiology, Washington, DC. 2013. pp. $765-801$

[23] Barata A, Caldeira J, Botelheiro R, Pagliara D, Malfeito-Ferreira M, Loureiro V. Survival patterns of Dekkera bruxellensis in wines and inhibitory effect of sulphur dioxide. International Journal of Food Microbiology. 2008;121(2):201-207

[24] Warth AD. Resistance of yeast species to benzoic and sorbic acids and to sulfur dioxide. Journal of Food Protection. 1985;48(7):564-569

[25] Stratford M, Anslow P. Evidence that sorbic acid does not inhibit yeast as a classic 'weak acid preservative'. Letters in Applied Microbiology. 1998;27(4):203-206

[26] Rojo MC, López FA, Lerena M, Mercado L, Torres A, Combina M. Evaluation of different chemical preservatives to control Zygosaccharomyces rouxii growth in high sugar culture media. Food Control. 2015;50:349-355

[27] Ough C, Crowell E. Use of sulfur dioxide in winemaking. Journal of Food Science. 1987;52(2):386-388

[28] Divol B, du Toit M, Duckitt E. Surviving in the presence of sulphur dioxide: Strategies developed by wine yeasts. Applied Microbiology and Biotechnology. 2012;95(3):601-613

[29] Santos MC, Nunes C, Saraiva JA, Coimbra MA. Chemical and physical methodologies for the replacement/reduction of sulfur dioxide use during winemaking: Review of their potentialities and limitations. European Food Research and Technology. 2012;234(1):1-12

[30] Guerrero RF, Cantos-Villar E. Demonstrating the efficiency of sulphur dioxide replacements in wine: A parameter review. Trends in Food Science and Technology. 2015,3;42(1):27-43

[31] Serpaggi V, Remize F, Recorbet G, Gaudot-Dumas E, Sequeira-Le Grand A, Alexandre H. Characterization of the "viable but nonculturable" (VBNC) state in the wine spoilage yeast Brettanomyces. Food Microbiology. 2012;30(2):438-447

[32] Agnolucci M, Rea F, Sbrana C, Cristani C, Fracassetti D, Tirelli A, et al. Sulphur dioxide affects culturability and volatile phenol production by Brettanomyces/Dekkera bruxellensis. International Journal of Food Microbiology. 2010;143(1):76-80

[33] Benito S, Palomero F, Morata A, Calderón F, Suárez-Lepe J. Factors affecting the hydroxycinnamate decarboxylase/vinylphenol reductase activity of Dekkera/Brettanomyces: Application for Dekkera/Brettanomyces control in red wine making. Journal of Food Science. 2009;74(1):M15-M22

[34] 27-CFR-24.246-2002 A. Code of Federal Regulations, Title 27, Chapter 1, Subchapter A, Part 24, Subpart L, Section 24.246. Materials Authorized for the Treatment of Wine and Juice. 2002. Available from: https://www.law.cornell.edu/cfr/text/27/24.246 [Accessed: 3 July 2017] 
[35] FAR A474-2004 A. Final Assessment Report, Application A474, Winemaking. Food Standards Australia New Zealand; 2004. Available from: http://www.foodstandards.gov.au/ code/applications/pages/applicationa474winemaking/index.aspx [Accessed: 3 July 2017]

[36] CR-EC 643-2006 A. Commission Regulation (EC) No 643/2006. Official Journal of the European Union, 28.4.2006, L115/6-L115/9. 27 April 2006. Available from: http://extwprlegs1.fao.org/docs/pdf/eur65203.pdf [Accessed: 3 July, 2017]

[37] Ough C, Langbehn L, Stafford P. Influence of $\mathrm{pH}$ and ethanol on the effectiveness of dimethyl dicarbonate in controlling yeast growth in model wine systems. American Journal of Enology and Viticulture. 1978;29(1):60-62

[38] Bizri JN, Wahem IA. Citric acid and antimicrobials affect microbiological stability and quality of tomato juice. Journal of Food Science. 1994;59(1):130-135

[39] Bartowsky E. Bacterial spoilage of wine and approaches to minimize it. Letters in Applied Microbiology. 2009;48(2):149-156

[40] Renouf V, Strehaiano P, Lonvaud-Funel A. Effectiveness of dimethyldicarbonate to prevent Brettanomyces bruxellensis growth in wine. Food Control. 2008;19(2):208-216

[41] Divol B, Strehaiano P, Lonvaud-Funel A. Effectiveness of dimethyldicarbonate to stop alcoholic fermentation in wine. Food Microbiology. 2005;22(2):169-178

[42] Delfini C, Gaia P, Schellino R, Strano M, Pagliara A, Ambrò S. Fermentability of grape must after inhibition with dimethyl dicarbonate (DMDC). Journal of Agriculture and Food Chemistry. 2002;50(20):5605-5611

[43] Costa A, Barata A, Malfeito-Ferreira M, Loureiro V. Evaluation of the inhibitory effect of dimethyl dicarbonate (DMDC) against wine microorganisms. Food Microbiology. 2008;25(2):422-427

[44] Zuehlke J, Glawe D, Edwards C. Efficacy of dimethyl dicarbonate against yeasts associated with Washington State grapes and wines. Journal of Food Processing and Preservation. 2014;39(6):1016-1026

[45] Oelofse A, Pretorius I, Du Toit M. Significance of Brettanomyces and Dekkera during winemaking: A synoptic review. South African Journal of Enology and Viticulture. 2008;29(2): 128-144

[46] Threlfall R, Morris J. Using dimethyldicarbonate to minimize sulfur dioxide for prevention of fermentation from excessive yeast contamination in juice and semi-sweet wine. Journal of Food Science. 2002;67(7):2758-2762

[47] Resolution Oeno 6/2006. Method OIV-MA-AS313-20. Determination of sorbic, benzoic and salicylic acid content in wine by the use of high-performance liquid chromatography. Compendium of International Analysis of Methods - OIV. Available from: http:// www.oiv.int/public/medias/2519/oiv-ma-as313-20.pdf [Accessed: 3 July 2017]

[48] Steels H, James S, Roberts I, Stratford M. Sorbic acid resistance: The inoculum effect. Yeast. 2000;16(13):1173-1183 
[49] Loureiro V, Malfeito-Ferreira M. Spoilage activities of Dekkera/Brettanomyces spp. In: Blackburn C, editor. Food Spoilage Microorganisms. Cambridge, UK: Woodhead Publisher; 2006. pp. 354-398

[50] Oswald TA, Edwards CG. Interactions between storage temperature and ethanol that affect growth of Brettanomyces bruxellensis in Merlot wine. American Journal of Enology and Viticulture. 2017;68:188-194. ajev. 2017.16102

[51] Couto JA, Neves F, Campos F, Hogg T. Thermal inactivation of the wine spoilage yeasts Dekkera/Brettanomyces. International Journal of Food Microbiology. 2005,Oct 25;104(3):337-344

[52] Zuehlke JM, Edwards CG. Impact of sulfur dioxide and temperature on culturability and viability of Brettanomyces bruxellensis in wine. Journal of Food Protection ${ }^{\circledR}$. 2013;76(12):2024-2030

[53] Wang C, Huang H, Hsu C, Yang BB. Recent advances in food processing using high hydrostatic pressure technology. Critical Reviews in Food Science and Nutrition. 2016;56(4):527-540

[54] Yaldagard M, Mortazavi SA, Tabatabaie F. The principles of ultra high pressure technology and its application in food processing/preservation: A review of microbiological and quality aspects. African Journal of Biotechnology. 2008;7(16):2739-2767

[55] Koutchma T, Popović V, Ros-Polski V, Popielarz A. Effects of ultraviolet light and highpressure processing on quality and health-related constituents of fresh juice products. Comprehensive Reviews in Food Science and Food Safety. 2016;15(5):844-867

[56] del Árbol JT, Pulido RP, La Storia A, Burgos MJG, Lucas R, Ercolini D, et al. Microbial diversity in pitted sweet cherries (Prunus avium L.) as affected by high-hydrostatic pressure treatment. Food Research International. 2016;89:790-796

[57] Pulido RP, Burgos MJG, Gálvez A, Lucas R. Changes in bacterial diversity of refrigerated mango pulp before and after treatment by high hydrostatic pressure. LWT-Food Science and Technology. 2017;78:289-295

[58] Shahbaz HM, Yoo S, Seo B, Ghafoor K, Kim JU, Lee D, et al. Combination of $\mathrm{TiO}_{2}-\mathrm{UV}$ photocatalysis and high hydrostatic pressure to inactivate bacterial pathogens and yeast in commercial apple juice. Food and Bioprocess Technology. 2016;9(1):182-190

[59] Martínez-Onandi N, Castioni A, San Martín E, Rivas-Cañedo A, Nuñez M, Torriani S, et al. Microbiota of high-pressure-processed Serrano ham investigated by culture-dependent and culture-independent methods. International Journal of Food Microbiology. 2017;241:298-307

[60] van Wyk S, Silva FV. High pressure inactivation of Brettanomyces bruxellensis in red wine. Food Microbiology. 2017;63:199-204

[61] González-Arenzana L, Sevenich R, Rauh C, López R, Knorr D, López-Alfaro I. Inactivation of Brettanomyces bruxellensis by high hydrostatic pressure technology. Food Control. 2016;59:188-195 
[62] Morata A, Loira I, Vejarano R, Bañuelos MA, Sanz PD, Otero L, et al. Grape processing by high hydrostatic pressure: Effect on microbial populations, phenol extraction and wine quality. Food and Bioprocess Technology. 2015;8(2):277-286

[63] Milani EA, Silva FV. Nonthermal pasteurization of beer by high pressure processing: Modelling the inactivation of Saccharomyces cerevisiae ascospores in different alcohol beers. High Pressure Research. 2016;36(4):595-609

[64] Turtoi M. Inactivation of Saccharomyces cerevisiae using new non-thermal technologies. A review. Romanian Biotechnological Letters. 2014;19(1):8901-8909

[65] Gomez-Lopez VM, Ragaert P, Debevere J, Devlieghere F. Pulsed light for food decontamination: A review. Trends in Food Science and Technology. 2007;18(9):464-473

[66] Takeshita K, Shibato J, Sameshima T, Fukunaga S, Isobe S, Arihara K, et al. Damage of yeast cells induced by pulsed light irradiation. International Journal of Food Microbiology. 2003;85(1):151-158

[67] Ferrario M, Alzamora SM, Guerrero S. Inactivation kinetics of some microorganisms in apple, melon, orange and strawberry juices by high intensity light pulses. Journal of Food Engineering. 2013;118(3):302-311

[68] Ferrario M, Alzamora SM, Guerrero S. Study of the inactivation of spoilage microorganisms in apple juice by pulsed light and ultrasound. Food Microbiology. 2015;46:635-642

[69] Luksiene Z, Buchovec I, Viskelis P. Impact of high-power pulsed light on microbial contamination, health promoting components and shelf life of strawberries. Food Technology and Biotechnology. 2013;51(2):284

[70] Ganan M, Hierro E, Hospital XF, Barroso E, Fernández M. Use of pulsed light to increase the safety of ready-to-eat cured meat products. Food Control. 2013;32(2):512-517

[71] Kotnik T, Frey W, Sack M, Meglič SH, Peterka M, Miklavčič D. Electroporation-based applications in biotechnology. Trends in Biotechnology. 2015;33(8):480-488

[72] Hülsheger H, Potel J, Niemann E. Electric field effects on bacteria and yeast cells. Radiation and Environmental Biophysics. 1983;22(2):149-162

[73] Gášková D, Sigler K, Janderova B, Plášek J. Effect of high-voltage electric pulses on yeast cells: Factors influencing the killing efficiency. Bioelectrochemistry and Bioenergetics. 1996;39(2):195-202

[74] Buckow R, Ng S, Toepfl S. Pulsed electric field processing of orange juice: A review on microbial, enzymatic, nutritional, and sensory quality and stability. Comprehensive Reviews in Food Science and Food Safety. 2013;12(5):455-467

[75] Aronsson K, Rönner U, Borch E. Inactivation of Escherichia coli, Listeria innocua and Saccharomyces cerevisiae in relation to membrane permeabilization and subsequent leakage of intracellular compounds due to pulsed electric field processing. International Journal of Food Microbiology. 2005;99(1):19-32 
[76] Ganeva V, Galutzov B, Teissie J. Evidence that pulsed electric field treatment enhances the cell wall porosity of yeast cells. Applied Biochemistry and Biotechnology. 2014;172(3):1540-1552

[77] Gómez-Rivas L, Escudero-Abarca BI, Aguilar-Uscanga MG, Hayward-Jones PM, Mendoza P, Ramírez M. Selective antimicrobial action of chitosan against spoilage yeasts in mixed culture fermentations. Journal of Industrial Microbiology and Biotechnology. 2004;31(1):16-22

[78] Raafat D, Sahl H. Chitosan and its antimicrobial potential-A critical literature survey. Microbial Biotechnology. 2009;2(2):186-201

[79] Roller S, Covill N. The antifungal properties of chitosan in laboratory media and apple juice. International Journal of Food Microbiology. 1999;47(1):67-77

[80] Ferreira D, Moreira D, Costa EM, Silva S, Pintado MM, Couto JA. The antimicrobial action of chitosan against the wine spoilage yeast Brettanomyces/Dekkera. Journal of Chitin and Chitosan Science. 2013;1(3):240-245

[81] Taillandier P, Joannis-Cassan C, Jentzer J, Gautier S, Sieczkowski N, Granes D, et al. Effect of a fungal chitosan preparation on Brettanomyces bruxellensis, a wine contaminant. Journal of Applied Microbiology. 2015;118(1):123-131

[82] Petrova B, Cartwright ZM, Edwards CG. Effectiveness of chitosan preparations against Brettanomyces bruxellensis grown in culture media and red wines. OENO One. 2016;50(1):49-56

[83] Iriti M, Vitalini S, Di Tommaso G, D-AMICO S, Borgo M, Faoro F. New chitosan formulation prevents grapevine powdery mildew infection and improves polyphenol content and free radical scavenging activity of grape and wine. Australian Journal of Grape and Wine Research. 2011;17(2):263-269

[84] Fajardo P, Martins J, Fuciños C, Pastrana L, Teixeira J, Vicente A. Evaluation of a chitosan-based edible film as carrier of natamycin to improve the storability of Saloio cheese. Journal of Food Engineering. 2010;101(4):349-356

[85] Souza JM, Caldas AL, Tohidi SD, Molina J, Souto AP, Fangueiro R, et al. Properties and controlled release of chitosan microencapsulated limonene oil. Revista Brasileira de Farmacognosia. 2014;24(6):691-698

[86] Elmacı SB, Gülgör G, Tokatlı M, Erten H, İşci A, Özçelik F. Effectiveness of chitosan against wine-related microorganisms. Antonie Van Leeuwenhoek. 2015;107(3):675-686

[87] Conner D, Beuchat L. Effects of essential oils from plants on growth of food spoilage yeasts. Journal of Food Science. 1984;49(2):429-434

[88] Curtis O, Shetty K, Cassagnol G, Peleg M. Comparison of the inhibitory and lethal effects of synthetic versions of plant metabolites (anethole, carvacrol, eugenol, and thymol) on a food spoilage yeast (Debaromyces hansenii). Food Biotechnology. 1996;10(1):55-73 
[89] Burt S. Essential oils: Their antibacterial properties and potential applications in foodsA review. International Journal of Food Microbiology. 2004;94(3):223-253

[90] Bennis S, Chami F, Chami N, Bouchikhi T, Remmal A. Surface alteration of Saccharomyces cerevisiae induced by thymol and eugenol. Letters in Applied Microbiology. 2004;38(6): 454-458

[91] Kubo I, Cespedes CL. Antifungal activity of alkanols: Inhibition of growth of spoilage yeasts. Phytochemistry Reviews. 2013;12(4):961-977

[92] Sivropoulou A, Papanikolaou E, Nikolaou C, Kokkini S, Lanaras T, Arsenakis M. Antimicrobial and cytotoxic activities of Origanum essential oils. Journal of Agricultural and Food Chemistry. 1996;44(5):1202-1205

[93] Chavan PS, Tupe SG. Antifungal activity and mechanism of action of carvacrol and thymol against vineyard and wine spoilage yeasts. Food Control. 2014;46:115-120

[94] Rabinkov A, Miron T, Konstantinovski L, Wilchek M, Mirelman D, Weiner L. The mode of action of allicin: Trapping of radicals and interaction with thiol containing proteins. Biochimica et Biophysica Acta (BBA)-General Subjects. 1998;1379(2):233-244

[95] Chang T, Jang H, Lin W, Duan P. Antifungal activities of commercial rice wine extracts of Taiwanese Allium fistulosum. Advances in Microbiology. 2016;6(07):471

[96] Oommen S, Anto RJ, Srinivas G, Karunagaran D. Allicin (from garlic) induces caspase-mediated apoptosis in cancer cells. European Journal of Pharmacology. 2004;485(1):97-103

[97] Lee J, Gupta S, Huang J, Jayathilaka LP, Lee B. HPLC-MTT assay: Anticancer activity of aqueous garlic extract is from allicin. Analytical Biochemistry. 2013;436(2):187-189

[98] Yoshida H, Katsuzaki H, Ishikawa K, Fukuda H, Fujino T, Suzuki A. Antimicrobial activity of the thiosulfinates isolated from oil-macerated garlic extract. Bioscience, Biotechnology, and Biochemistry. 1999;63(3):591-594

[99] Shadkchan Y, Shemesh E, Mirelman D, Miron T, Rabinkov A, Wilchek M, et al. Efficacy of allicin, the reactive molecule of garlic, in inhibiting Aspergillus spp. in vitro, and in a murine model of disseminated aspergillosis. Journal of Antimicrobial Chemotherapy. 2004 May;53(5):832-836

[100] Ankri S, Mirelman D. Antimicrobial properties of allicin from garlic. Microbial Infections. 1999;1(2):125-129

[101] Cobos R, Mateos RM, Alvarez-Perez JM, Olego MA, Sevillano S, Gonzalez-Garcia S, et al. Effectiveness of natural antifungal compounds in controlling infection by grapevine trunk disease pathogens through pruning wounds. Applied Environmental Microbiology. 2015 Sep;81(18):6474-6483

[102] Davis SR. An overview of the antifungal properties of allicin and its breakdown products - The possibility of a safe and effective antifungal prophylactic. Mycoses. 2005;48(2):95-100 
[103] Marchese A, Barbieri R, Sanches-Silva A, Daglia M, Nabavi SF, Jafari NJ, et al. Antifungal and antibacterial activities of allicin: A review. Trends in Food Science and Technology. 2016;52:49-56

[104] Chang Y, McLandsborough L, McClements DJ. Physical properties and antimicrobial efficacy of thyme oil nanoemulsions: Influence of ripening inhibitors. Journal of Agriculture and Food Chemistry. 2012;60(48):12056-12063

[105] Maté J, Periago PM, Palop A. When nanoemulsified, d-limonene reduces Listeria monocytogenes heat resistance about one hundred times. Food Control. 2016;59:824-828

[106] Blanco-Padilla A, Soto KM, Hernandez Iturriaga M, Mendoza S. Food antimicrobials nanocarriers. Scientific World Journal. 2014;2014:837215

[107] Fogaça AC, Lorenzini DM, Kaku LM, Esteves E, Bulet P, Daffre S. Cysteine-rich antimicrobial peptides of the cattle tick Boophilus microplus: Isolation, structural characterization and tissue expression profile. Developmental \& Comparative Immunology. 2004;28(3):191-200

[108] Schibli DJ, Epand RF, Vogel HJ, Epand RM. Tryptophan-rich antimicrobial peptides: Comparative properties and membrane interactions. Biochemistry and Cell Biology. 2002;80(5):667-677

[109] Jung HJ, Park Y, Hahm K, Lee DG. Biological activity of Tat (47-58) peptide on human pathogenic fungi. Biochemical and Biophysical Research Communications. 2006;345(1):222-228

[110] Chan DI, Prenner EJ, Vogel HJ. Tryptophan-and arginine-rich antimicrobial peptides: Structures and mechanisms of action. Biochimica et Biophysica Acta (BBA)Biomembranes. 2006;1758(9):1184-1202

[111] Zhao H, Mattila J, Holopainen JM, Kinnunen PK. Comparison of the membrane association of two antimicrobial peptides, magainin 2 and indolicidin. Biophysics Journal. 2001;81(5):2979-2991

[112] Schibli DJ, Hwang PM, Vogel HJ. Structure of the antimicrobial peptide tritrpticin bound to micelles: A distinct membrane-bound peptide fold. Biochemistry. 1999;38(51):16749-16755

[113] Salay LC, Procopio J, Oliveira E, Nakaie CR, Schreier S. Ion channel-like activity of the antimicrobial peptide tritrpticin in planar lipid bilayers. FEBS Letters. 2004;565(1-3):171-175

[114] Yang S, Shin SY, Kim Y, Kim Y, Hahm K, Kim JI. Conformation-dependent antibiotic activity of tritrpticin, a cathelicidin-derived antimicrobial peptide. Biochemical and Biophysical Research Communications. 2002;296(5):1044-1050

[115] Nguyen LT, de Boer L, Zaat SA, Vogel HJ. Investigating the cationic side chains of the antimicrobial peptide tritrpticin: Hydrogen bonding properties govern its membrane-disruptive activities. Biochimica et Biophysica Acta (BBA)-Biomembranes. 2011;1808(9):2297-2303 
[116] Tang Y, Shi Y, Zhao W, Hao G, Le G. Discovery of a novel antimicrobial peptide using membrane binding-based approach. Food Control. 2009;20(2):149-156

[117] Tomie T, Ishibashi J, Furukawa S, Kobayashi S, Sawahata R, Asaoka A, et al. Scarabaecin, a novel cysteine-containing antifungal peptide from the rhinoceros beetle, Oryctes rhinoceros. Biochemical and Biophysical Research Communications.2003;307(2):261-266

[118] Yang S, Shin SY, Lee CW, Kim Y, Hahm K, Kim JI. Selective cytotoxicity following Argto-Lys substitution in tritrpticin adopting a unique amphipathic turn structure. FEBS Letters. 2003;540(1-3):229-233

[119] Subbalakshmi C, Sitaram N. Mechanism of antimicrobial action of indolicidin. FEMS Microbiology Letters. 1998 Mar 1;160(1):91-96

[120] Falla TJ, Karunaratne DN, Hancock RE. Mode of action of the antimicrobial peptide indolicidin. Journal of Biological Chemistry. 1996;271(32):19298-19303

[121] Ladokhin AS, Selsted ME, White SH. Bilayer interactions of indolicidin, a small antimicrobial peptide rich in tryptophan, proline, and basic amino acids. Biophysics Journal. 1997;72(2):794-805

[122] Rozek A, Friedrich CL, Hancock RE. Structure of the bovine antimicrobial peptide indolicidin bound to dodecylphosphocholine and sodium dodecyl sulfate micelles. Biochemistry. 2000;39(51):15765-15774

[123] Friedrich CL, Rozek A, Patrzykat A, Hancock RE. Structure and mechanism of action of an indolicidin peptide derivative with improved activity against gram-positive bacteria. Journal of Biological Chemistry. 2001 Jun 29;276(26):24015-24022

[124] Marchand C, Krajewski K, Lee HF, Antony S, Johnson AA, Amin R, et al. Covalent binding of the natural antimicrobial peptide indolicidin to DNA abasic sites. Nucleic Acids Research. 2006;34(18):5157-5165

[125] Lee DG, Kim HK, Am Kim S, Park Y, Park S, Jang S, et al. Fungicidal effect of indolicidin and its interaction with phospholipid membranes. Biochemical and Biophysical Research Communications. 2003;305(2):305-310

[126] Bellamy W, Takase M, Wakabayashi H, Kawase K, Tomita M. Antibacterial spectrum of lactoferricin B, a potent bactericidal peptide derived from the $\mathrm{N}$-terminal region of bovine lactoferrin. Journal of Applied Bacteriology. 1992;73(6):472-479

[127] Vogel HJ, Schibli DJ, Jing W, Lohmeier-Vogel EM, Epand RF, Epand RM. Towards a structure-function analysis of bovine lactoferricin and related tryptophan-and arginine-containing peptides. Biochemistry and Cell Biology. 2002;80(1):49-63

[128] Enrique M, Marcos JF, Yuste M, Martínez M, Vallés S, Manzanares P. Inhibition of the wine spoilage yeast Dekkera bruxellensis by bovine lactoferrin-derived peptides. International Journal of Food Microbiology. 2008;127(3):229-234 
[129] Enrique M, Marcos JF, Yuste M, Martínez M, Vallés S, Manzanares P. Antimicrobial action of synthetic peptides towards wine spoilage yeasts. International Journal of Food Microbiology. 2007;118(3):318-325

[130] Frank JF. Milk and Dairy Products. Food Microbiology: Fundamentals and Frontiers. 3rd ed. American Society of Microbiology, Washington, DC. 2007. pp. 141-155

[131] Duan J, Park S, Daeschel M, Zhao Y. Antimicrobial chitosan-lysozyme (CL) films and coatings for enhancing microbial safety of mozzarella cheese. Journal of Food Science. 2007;72(9):M355-M362

[132] Ryge T, Doisy X, Ifrah D, Olsen J, Hansen P. New indolicidin analogues with potent antibacterial activity. The Journal of Peptide Research. 2004;64(5):171-185

[133] Benincasa M, Scocchi M, Pacor S, Tossi A, Nobili D, Basaglia G, et al. Fungicidal activity of five cathelicidin peptides against clinically isolated yeasts. Journal of Antimicrobial Chemotherapy. 2006 Nov;58(5):950-959

[134] Sader HS, Fedler KA, Rennie RP, Stevens S, Jones RN. Omiganan pentahydrochloride (MBI 226), a topical 12-amino-acid cationic peptide: Spectrum of antimicrobial activity and measurements of bactericidal activity. Antimicrobial Agents and Chemotherapy. 2004 Aug;48(8):3112-3118

[135] Krajewski K, Marchand C, Long Y, Pommier Y, Roller PP. Synthesis and HIV-1 integrase inhibitory activity of dimeric and tetrameric analogs of indolicidin. Bioorganic \& Medicinal Chemistry Letters. 2004;14(22):5595-5598

[136] Vorland LH, Ulvatne H, Andersen J, Haukland HH, Rekdal $\varnothing$, Svendsen JS, et al. Lactoferricin of bovine origin is more active than lactoferricins of human, murine and caprine origin. Scandinavian Journal of Infectious Diseases. 1998;30(5):513-517

[137] Bussey H. K1 killer toxin, a pore-forming protein from yeast. Molecular Microbiology. 1991;5(10):2339-2343

[138] Villalba ML, Sáez JS, del Monaco S, Lopes CA, Sangorrín MP. TdKT, a new killer toxin produced by Torulaspora delbrueckii effective against wine spoilage yeasts. International Journal of Food Microbiology. 2016;217:94-100.

[139] Oro L, Ciani M, Bizzaro D, Comitini F. Evaluation of damage induced by Kwkt and Pikt zymocins against Brettanomyces/Dekkera spoilage yeast, as compared to sulphur dioxide. Journal of Applied Microbiology. 2016;121:207-214.

[140] Comitini F, Di Pietro N, Zacchi L, Mannazzu I, Ciani M. Kluyveromyces phaffii killer toxin active against wine spoilage yeasts: Purification and characterization. Microbiology. 2004;150(8):2535-2541

[141] Oro L, Zara S, Fancellu F, Mannazzu I, Budroni M, Ciani M, et al. TpBGL2 codes for a Tetrapisispora phaffii killer toxin active against wine spoilage yeasts. FEMS Yeast Research. 2014 May;14(3):464-471 
[142] Anonymous N. Tetrapisispora phaffii. 2011. Available from: https://www.ncbi.nlm.nih. gov/genome/?term=Tetrapisispora+phaffii [Accessed: July 3, 2017]

[143] Maqueda M, Zamora E, Alvarez ML, Ramirez M. Characterization, ecological distribution, and population dynamics of Saccharomyces sensu stricto killer yeasts in the spontaneous grape must fermentations of southwestern Spain. Applied and Environmental Microbiology. 2012 Feb;78(3):735-743

[144] Marquina D, Santos A, Peinado J. Biology of killer yeasts. International Microbiology. 2002;5(2):65-71

[145] Enrique M, Ibáñez A, Marcos J, Yuste M, Martinez M, Vallés S, et al. $\beta$-glucanases as a tool for the control of wine spoilage yeasts. Journal of Food Science. 2010;75(1):M41-M45

[146] Mehlomakulu NN, Setati ME, Divol B. Characterization of novel killer toxins secreted by wine-related non-Saccharomyces yeasts and their action on Brettanomyces spp. International Journal of Food Microbiology. 2014;188:83-91

[147] Santos A, Navascués E, Bravo E, Marquina D. Ustilago maydis killer toxin as a new tool for the biocontrol of the wine spoilage yeast Brettanomyces bruxellensis. International Journal of Food Microbiology. 2011;145(1):147-154

[148] García M, Esteve-Zarzoso B, Arroyo T. Non-Saccharomyces yeasts: Biotechnological role for wine production. In Grape and Wine Biotechnology. InTech. 2016

[149] Longin C, Petitgonnet C, Guilloux-Benatier M, Rousseaux S, Alexandre H. Application of flow cytometry to wine microorganisms. Food Microbiology. 2017April;62:221-231

[150] Malacrinò P, Zapparoli G, Torriani S, Dellaglio F. Rapid detection of viable yeasts and bacteria in wine by flow cytometry. Journal of Microbiology Methods. 2001;45(2):127-134

[151] Veal D, Deere D, Ferrari B, Piper J, Attfield P. Fluorescence staining and flow cytometry for monitoring microbial cells. Journal of Immunological Methods. 2000;243(1):191-210

[152] Walker GM. Yeasts. Desk Encyclopedia of Microbiology. 2nd ed. London: Elsevier/ Academic Press; 2009

[153] Khiyami MA, Almoammar H, Awad YM, Alghuthaymi MA, Abd-Elsalam KA. Plant pathogen nanodiagnostic techniques: Forthcoming changes? Biotechnology \& Biotechnological Equipment. 2014;28(5):775-785

[154] Lim DV, Simpson JM, Kearns EA, Kramer MF. Current and developing technologies for monitoring agents of bioterrorism and biowarfare. Clinical Microbiology Reviews. 2005 Oct;18(4):583-607

[155] Goddard G, Martin JC, Naivar M, Goodwin PM, Graves SW, Habbersett R, et al. Single particle high resolution spectral analysis flow cytometry. Cytometry Part A. 2006;69(8):842-851

[156] Watson DA, Gaskill DF, Brown LO, Doorn SK, Nolan JP. Spectral measurements of large particles by flow cytometry. Cytometry Part A. 2009;75(5):460-464 